\title{
COMPETITIVE BIOSORPTION OF CHROMIUM AND LEAD INTO SALVINIA NATANS MACROPHYTE
}

\author{
L. K. S. LIMA ${ }^{1}$, C. E. BENTO ${ }^{1}$, M. G. C. SILVA ${ }^{1}$ and M. G. A. VIEIRA ${ }^{1 *}$ \\ ${ }^{1}$ University of Campinas, Department of Processes and Products Design \\ Email: melissagav@feq.unicamp.br
}

\begin{abstract}
Salvinia natansmacrophyte has been studied as a potential biosorbent for metal ions removal. We investigated in this work the performance of the macrophyte in recovery of lead and chromium from bicomponent synthetic solution from two different systems, batch and fixed bed. Equilibrium data were obtained by batch system through isotherms and fitted toLangmuir and Langmuir-Freundlich models. The breakthrough curves were performed at three different concentrations ratio. In order to know the biosorption mechanism FT-IR analyses were performed for $S$. natans before and after uptake of metal ions. The results showed different functional groups on the biomass surface and the ability of these groups bind with $\mathrm{Cr}^{+3}$ and $\mathrm{Pb}^{2+}$ ions in aqueous solution.
\end{abstract}

\section{INTRODUCTION}

Metal ions as chromium and lead are chemical elements toxic to the environment and human body and belong to the most important groups of pollutants from industrial wastewater. The harmful potential of metals associated with their power of accumulation in the environment and their toxic effects, and potential damage to health is well known and extensively studied (Axtell et al., 2003; Shenget al., 2004;Saygidegeret al., 2005).

These kind of pollutants are very difficult to treat due, mainly, to the inefficiency and/or the high cost related to the traditional methods. Biosorption is an alternative method of treatment which has become increasingly promising, due to the large variety of existing materials and the high affinity for metal ionsVieira et al., 2008;Leyva-Ramoset al., 2012).

The biosorption is a purification process which may involve complex mechanisms, which depends on the chemical and morphological characteristics of the biological material used (Lima et al., 2011). The term "biosorption" refers to various ways of removing the nonactive biomass, where the "sequestration" of pollutants by the biomass of the cell wall may occur via mechanisms of adsorption, ion exchange, chelation, coordination, complexation, etc. (Bai and Abraham, 2001). This "sequestration" can be attributed to functional groups present in the cell wall of biomass such as carboxylates, carboxylic, phosphates, amines, aldehydes (Saygidegeret al., 2005;Bernardoet al., 2009).

Among all kind ofbiomaterialsexisting we can mention the aquatic macrophytes.They have some advantages such as low-cost and locally available material. They are easy to growingin a wide range of temperature and $\mathrm{pH}$. Moreover, many works have shown the high affinity of the metal ions by macrophytes in adsorption process (Lima et al., 2011). Wang and 
Qin (2006)have tested the biomass of aquatic macrophyte Alternantheraphiloxeroides in removal of $\mathrm{Ni}^{2+}, \mathrm{Zn}^{2+}$ and $\mathrm{Cr}^{6+}$ ions. The Langmuir model fitted to the experimental data showed the maximum removal capacity, $q_{\max }$, of $0.723,0.343$ and $0.279 \mathrm{mmol} . \mathrm{g}^{-1}$ forCr ${ }^{6+}, \mathrm{Zn}^{2+}$ and $\mathrm{Ni}^{2+}$, respectively.

Bunluesinet al., 2007 studied the removal of $\mathrm{Cd}^{2+}$ by the nonliving biomass of aquatic macrophyte Hydrillaverticillata. They tested batch and fixed-bed systems. The Langmuir model fitted to the batch data showed the maximum removal capacity, $q_{\max }$, of $0.133 \mathrm{mmol} . \mathrm{g}^{-1}$. From fixed-bed experiments, the breakthrough curves showed that $H$. verticillata was capable of decreasing $\mathrm{Cd}^{2+}$ concentration from $10 \mathrm{mg} . \mathrm{L}^{-1}$ to a value below the detection limit of $0.02 \mathrm{mg} \cdot \mathrm{L}^{-1}$.

Miretzky and Munõz (2011) evaluated the removal of $\mathrm{Zn}^{2+}$ by Eichhorniacrassipesmacrophyte biomass modified by Fenton treatment. The efficiency of the $\mathrm{Zn}^{2+}$ sorption process under different experimental conditions was determined and experimental datashowed goodfitting to Langmuir model with maximum sorptioncapacity of 0.114 and $0.203 \mathrm{mmol} \mathrm{g}^{-1}$ for raw and Fenton activated biomass (dose $5.0 \mathrm{~g} \mathrm{~L}^{-1}, \mathrm{pH} 6.0$ ), respectively.

Therefore, the main of this work is to study the application of the aquatic macrophyte Salvinia natans in the removal of $\mathrm{Pb}^{2+}$ and $\mathrm{Cr}^{3+}$ ions from binary mixture solution in batch and fixed bed system.Equilibrium and breakthrough curves experiments were performed. The Langmuir and Langmuir-Freundlich isotherm models were applied to experimental data. The changes in functional groups were analyzed by spectroscopy in the infrared region (FT-IR).

\section{MATERIALS AND METHODS}

\subsection{Biomass}

Salvinia natans macrophyte was cultivated and collected by the CPAA (Research Center in Environmental Aquaculture) of State University of Paraná, Brazil. After collected the biomass was washed and dried at $55^{\circ} \mathrm{C}$ for $24 \mathrm{~h}$. After this periodthe biomass was sieved and fractions measuring $0.855 \mathrm{~mm}$ were collected and used in batch and fixed bed experiments.

\subsection{Metal ions solutions}

The chromium and lead synthetic solutions were prepared dissolving $\mathrm{Cr}\left(\mathrm{NO}_{3}\right)_{3} \cdot 9 \mathrm{H}_{2} \mathrm{O}$ salt and $\mathrm{Pb}\left(\mathrm{NO}_{3}\right)_{2}$ (both trade Vetec) in deionized water. The $\mathrm{pH}$ of the solution was adjusted to 4 using $\mathrm{HNO}_{3}(0.5 \mathrm{M})$ and $\mathrm{NaOH}(1 \mathrm{M})$.

\subsection{Fourier transforms infrared spectroscopy (FT-IR)}

FT-IR analysis was accomplished with the aim of observe the functional groups present in biomass and the changes in these groups after biosorption process. The Infrared spectra were recorded in the $4000-600 \mathrm{~cm}^{-1}$ region using a Thermo Nicolet instrument, model IR-200. The ATR (attenuated total reflection) device allows getting information about the biomass surface. 


\subsection{Equilibrium assays}

The equilibrium experiments were carried out by mixing $100 \mathrm{~mL}$ of solution with different concentrations combinations of $\mathrm{Cr}^{3+}$ and $\mathrm{Pb}^{2+}$ (Table 1)with $0.2 \mathrm{~g}$ of $S$. natans at roomtemperature and $\mathrm{pH} 4$. The solution with the biomass was maintained under stirring for a period of $2 \mathrm{~h}$, time enough to reach the equilibrium. Then the samples were centrifuged and concentrations of the metal ions were determined by Atomic Absorption Spectrophotometry (AAS). The adsorption capacity was calculated by Eq. 1 .

$$
q=\frac{\left(C_{0}-C_{f}\right) \cdot V}{m}
$$

where $q$ is the metal ion uptake $\left(\mathrm{mmol} . \mathrm{g}^{-1}\right), \mathrm{C}_{0}$ and $\mathrm{C}_{\mathrm{f}}$ are the initial and equilibrium concentrations of the metal ion (mmol. $\left.\mathrm{L}^{-1}\right), V$ is the volume of solution $(\mathrm{L}), m$ is the weight of biomass (g).

Table 1 - Concentrations used in binary mixture for equilibriumassays.

\begin{tabular}{cc}
\hline \multicolumn{2}{c}{ Metal ion concentration $\left(\mathrm{mmol} . \mathrm{L}^{-1}\right)$} \\
\hline $\mathrm{Cr}^{3+}$ & $\mathrm{Pb}^{2+}$ \\
\hline 0.25 & 0.25 \\
0.25 & 0.75 \\
0.75 & 0.75 \\
1.00 & 2.00 \\
2.00 & 1.00 \\
2.00 & 2.00 \\
\hline
\end{tabular}

\subsection{Dynamic System assays}

The breakthrough curves were obtainedusing aglass columnwith $1.5 \mathrm{~cm}$ innerdiameter and $15 \mathrm{~cm}$ high. The biomass wasinserted into thecolumnandwashed withdeionizedwater for about 2hoursuntilall thinresidueof the biomasshas been removed. The columnwas fedwithabicomponent synthetic solutionof lead and chromium with ratio of concentrations showed in Table 2, using a peristalticpump,Masterflexbrand, at afixed flow rate of $1 \mathrm{~mL} \cdot \mathrm{min}^{-1}$ and $\mathrm{pH}$ of 4.Afraction collector(FC203 Fraction Collector) was used to collect aliquots at different periods of time. After this they werediluted and measuredon anAtomic AbsorptionSpectrophotometer (Shimadzu AA 7000). The length of themass transferarea (MTZ) and the useful $\left(\mathrm{q}_{\mathrm{u}}\right)$ and total $\left(\mathrm{q}_{\mathrm{t}}\right)$ amounts removedby the columnwere calculatedas a function oftime according to Geankoplis' method (1993). Amass balancewas performedon the columnusing the dataobtainedfromthesaturation, in which the areaunder the curve $\left(1-\mathrm{C} / \mathrm{C}_{0}\right)$ until the breaking pointis proportionalto $\mathrm{q}_{\mathrm{u}}($ Equation 1), and the area up tothe saturation ofbed isproportional toq $\mathrm{t}_{\mathrm{t}}\left(\right.$ Equation 2). The pointof rupture wasconsideredat a time $\left(\mathrm{t}_{\mathrm{b}}\right)$, where the concentration atthe column outletequivalent to5\% of the initial feed concentration.

$q_{u}=\frac{C_{0} \cdot Q}{1000 \cdot m} \int_{0}^{t_{b}}\left(1-\frac{\left.C\right|_{z=L}}{C_{0}}\right) d t$ 
$q_{t}=\frac{C_{0} \cdot Q}{1000 \cdot m} \int_{0}^{t_{t 0 t}}\left(1-\frac{\left.C\right|_{z=L}}{C_{0}}\right) d t$

Where, $\left.\mathrm{C}\right|_{\mathrm{z}=\mathrm{L}}$ isthe concentration ofchromium and leadin solutionat the outletof the column and $\mathrm{C}_{0}$ is the concentration of both metals incolumn feedin mmol. $\mathrm{L}^{-1}$.

Themass transferzone(MTZ) was calculatedusing Equation3based on theratio between $q_{u} / q_{t}$.

$Z T M=H_{L} \cdot\left(1-\frac{q_{u}}{q_{t}}\right)$

Table 2 -Ratio of concentrations used in binary mixture for fixed-bed assays.

\begin{tabular}{ccc}
\multirow{2}{*}{ Ratio } & \multicolumn{2}{c}{ Metal ion concentration $\left(\mathrm{mmol} . \mathrm{L}^{-1}\right)$} \\
\cline { 2 - 3 } & $\mathrm{Cr}^{3+}$ & $\mathrm{Pb}^{2+}$ \\
\hline 1 & 1.0 & 1.0 \\
2 & 1.0 & 2.0 \\
3 & 2.0 & 1.0 \\
\hline
\end{tabular}

\section{RESULTS AND DISCUSSION}

\subsection{Fourier transforms infrared spectroscopy (FT-IR)}

Figure 1 shows the peaks and bands of functional groups obtained byinfraredspectroscopy. The importance of this analysis is to show the functional groups present on the biomass and if they were modified with the biosorption process. The raw biomass presented the band at $3442 \mathrm{~cm}^{-1}$ corresponding to the vibration of $\mathrm{OH}$. The weak peak at $2360 \mathrm{~cm}^{-1}$ assigned to phosphonates. The peak at $1640 \mathrm{~cm}^{-1}$ corresponding to $\mathrm{C}=\mathrm{O}$ of amide. $1130-1000 \mathrm{~cm}^{-1}$ is vibration of C-O-C and O-H of polysaccharides. The peak at 914 $\mathrm{cm}^{-1}$ is assigned to $\mathrm{C}$-Xof the groupsofhalogens. The bands $<800 \mathrm{~cm}^{-1}$ are finger print zone which are phosphateand sulphur functional groups (Saygidegeret al., 2005). After the biosorption process with the mixture of $\mathrm{Cr}^{3+}$ and $\mathrm{Pb}^{2+}$ some functional groups of $S$. natans are losing, which implies that these groups participate of the uptake of both metal ions. In other words, the biomass have different functional groups for heavy metal binding such as phosphonates, halogenated, amide and hydroxidegroups (Saygidegeret al., 2005). 


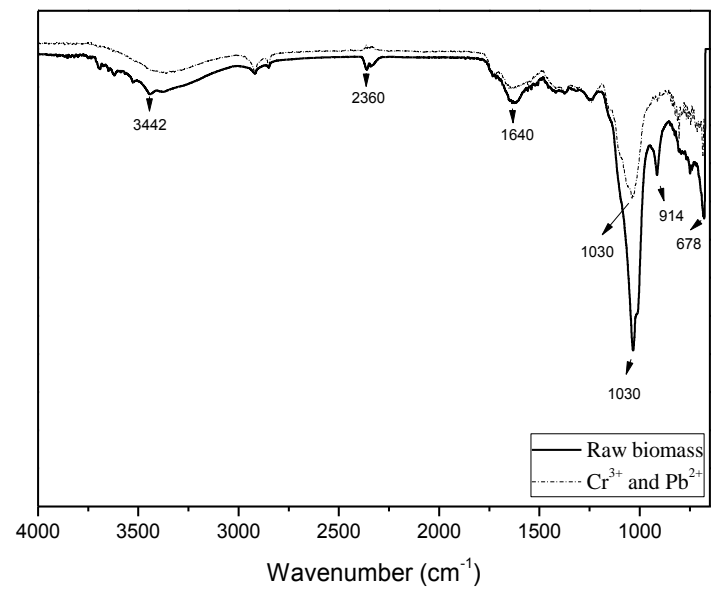

Figure 1 - FT-IR spectra of raw $S$. natans and the biomass saturated with chromium and lead.

\subsection{Equilibrium assays}

Figure 2 shows the adsorption equilibriumfrom bicomponent mixture of $\mathrm{Cr}^{3+}$ and $\mathrm{Pb}^{2+}$. For the studied metals, we can observe that lead had a higher amount of removal from the solution than chromium. Which means that $\mathrm{Pb}^{2+}$ has high affinity with the active sites of the cell wall of the biomass. The results are in accordance with found in previous work (Lima et al., 2012)using the $S$. Natans biomass in removal of lead present in a single component solution. We found that lead had a high removal capacity with $q_{\max }$ of $0.614 \mathrm{mmol. \textrm {g } ^ { - 1 }}$, much higher than that found in other work (Lima et al., 2012) for chromium removal by the same biomass, which obtained amaximum removal capacity of $0.243 \mathrm{mmol} . \mathrm{g}^{-1}$.In both papers the parameter $b$ from Langmuir modelwas 13.308 and $19.251 \mathrm{~L} . \mathrm{mmol}^{-1}$ forchromium and lead, respectively.

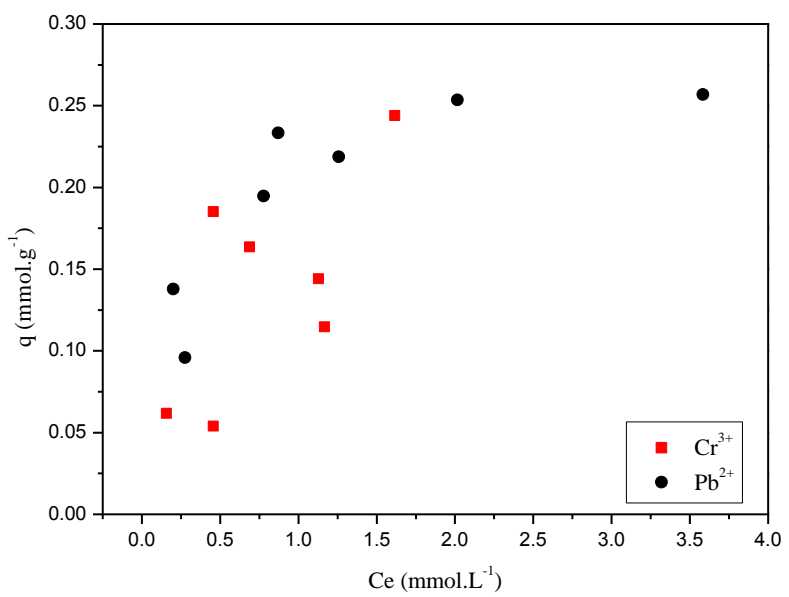

Figure 2 - Equilibrium isotherms of binary system of $\mathrm{Cr}^{3+}$ and $\mathrm{Pb}^{2+}$.

\subsection{Dynamic System assays}

In orderto knowthe influenceof the feed concentrationin the biosorption process,experiments were performedin 3 different ratios of concentrations at flow rateof $1 \mathrm{~mL} \cdot \mathrm{min}^{-1}$ and $\mathrm{pH}$ 4.Figure 3 showsthebreakthrough curvesat the experimental conditions 
forthe removal of $\mathrm{Cr}^{3+}$ and $\mathrm{Pb}^{2+}$. We can observe that for all ratios the residence time was higher for lead. When concentration of $\mathrm{Cr}^{3+}$ increases, the residence time of both metal ions in column decreases. The same happens when the concentration of $\mathrm{Pb}^{2+}$ increases. It means that when we increased the concentration of metal ions in solution there were a greatercompetitionforactive sitesof thebiomass. These results are similar to those found by many researchers in a single and multicomponentsystems of biosorption in columns for different metal ions and using different adsorbents (Caleroet al., 2009; Vijayaraghavanet al., 2005; Carmona et al., 2012; Vilaret al., 2008). Thehigher biosorbentaffinities for $\mathrm{Pb}^{2+}$ can causes the $\mathrm{Cr}^{3+}$ displacementfrom the biosorbent surfaces.
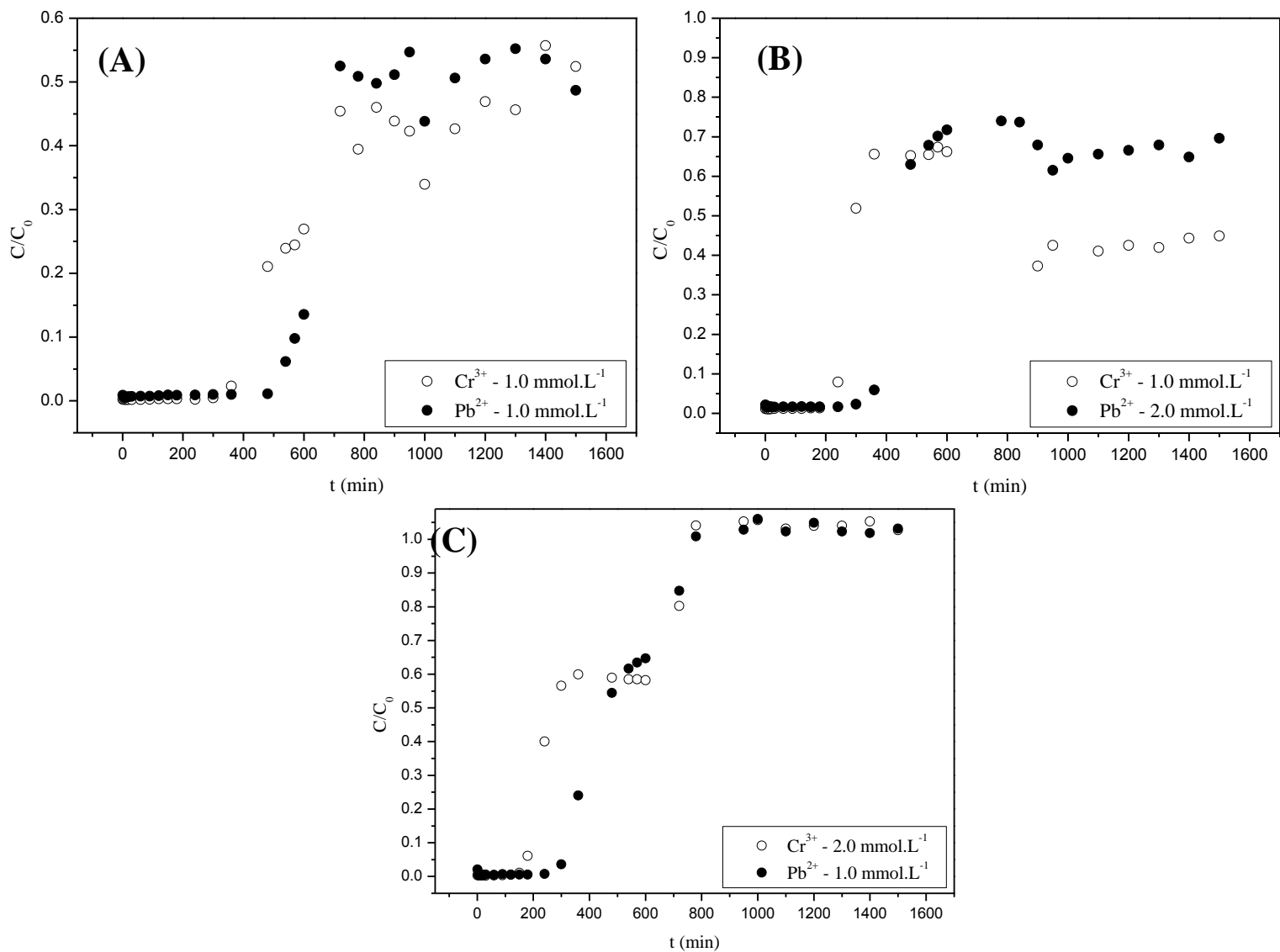

Figure 3 -Breakthrough curves for the removal of $\mathrm{Cr}^{3+}$ and $\mathrm{Pb}^{2+}$ for (a) ratio 1, (b) ratio 2 and (c) ratio 3 .

TheMTZhas abed height $\left(\mathrm{H}_{\mathrm{L}}\right)$ corresponding tothe maximum value.The smallerthe area (value of MTZ), the better theefficiencyof mass transfer. The parameters obtained through experimental dataare shownin Table 3. From the data we can observe that the higher value of MTZ, or resistance to mass transfer, is for $\mathrm{Cr}^{3+}$ at a ratio 3 , when chromium concentration is higher. This is truesince theresidencetimeof chromiumin the columnwas lower. For the three ratios, the MTZ for chromium is higher than for lead. The higher MTZ for lead was gotten when the concentration for both metals were equal (ratio 1). However, at this condition the better result of $q_{u}$ (about $0.125 \mathrm{mmol} . \mathrm{g}^{-1}$ ) for lead was obtained. This value can be explained since at this ratio the time of residence is higher in column. Vilaret al., (2008) found a similar result for a binary system of $\mathrm{Cu}^{2+}$ and $\mathrm{Pb}^{2+}$ removal from aqueous solution by algae Gelidium. 
The authors found that lead had more affinity with lead ions and alsoa lower MTZ than copper.

Table3-Chromium and lead adsorption parameters in fixed bed.

\begin{tabular}{ccccc} 
Ratio & Metal Ion & $\begin{array}{c}\text { MTZ } \\
(\mathrm{cm})\end{array}$ & $\begin{array}{c}q_{u} \\
\left(\mathrm{mmol.g} \mathrm{g}^{-1}\right)\end{array}$ & $\begin{array}{c}q_{t} \\
\left(\mathrm{mmol.g} \mathrm{g}^{-1}\right)\end{array}$ \\
\hline \multirow{2}{*}{1} & $\mathrm{Cr}^{3+}$ & 8.169 & 0.108 & 0.237 \\
& $\mathrm{~Pb}^{2+}$ & 6.994 & 0.125 & 0.234 \\
2 & $\mathrm{Cr}^{3+}$ & 9.352 & 0.124 & 0.329 \\
& $\mathrm{~Pb}^{2+}$ & 6.286 & 0.098 & 0.169 \\
\multirow{2}{*}{3} & $\mathrm{Cr}^{3+}$ & 9.678 & 0.034 & 0.096 \\
& $\mathrm{~Pb}^{2+}$ & 5.643 & 0.074 & 0.119 \\
\hline
\end{tabular}

\section{CONCLUSIONS}

This work evaluated the removal of a bicomponent mixture of chromium and lead using the aquatic macrophyte Salvinia natans in batch and dynamic system. From the FT-IR characterization we observed that the biomass have different functional groups for heavy metal binding such as phosphonates, halogenated, amide and hydroxide groups. The equilibrium data showed that lead have more affinity for the active sites of the biomass than chromium as shown in previous work for single components study. The fixed-bed experiments showed that the concentration of metal ions have an influence in the adsorption process. The higher theconcentrationof metal ions theloweris the metalremoval capacityof the column. The MTZ was higher to chromium ions for all the three ratios studied. Results showed the possibility of using the aquatic macrophyte Salvinia natans in batch and fixed-bed systems.

\section{Acknowledgement}

The authors acknowledge the financial support received from $\mathrm{CNPq}$ and Foundation for Research Support of São Paulo State, FAPESP, for this research.

\section{REFERENCES}

AXTELL, N. R.; STERNBERG, S. P. K.; CLAUSSEN, K. Lead and nickel removal using Microspora and Lemna minor. Bioresour. Technol. v. 89, n. 1, p. 41-48, 2003.

BAI, R. S.; ABRAHAM, E. Biosorption of $\mathrm{Cr}$ (VI) from aqueous solution byRhizoupusnigricans.Bioresour. Technol. v. 79, p. 73-81, 2001.

BERNARDO, G. R. R.; RENE, R. M. J.; CATALINA,A. T .M. Chromium (III) uptake by agro-waste biosorbents: chemical characterization, sorption-desorption studies, and mechanism. J. Hazard. Mater. v. 170, n. 2-3, p. 845-854, 2009.

BUNLUESIN, S.; KRUATRACHUE, M.; POKETHITIYOOK, P.; UPATHAM, S.; LANZA, G. R.Batch and continuous packed column studies of cadmium biosorption by Hydrillaverticillatabiomass. J. Biosci. Bioeng. v. 103, p.509-513, 2007. 
CARMONA, M. E. R.; SILVA, M. A. P.; LEITE, S. G. F.; ECHEVERRI, O. H. V.; LÓPEZ, C. O. Packed bed redistribution system for $\mathrm{Cr}(\mathrm{III})$ and $\mathrm{Cr}(\mathrm{VI})$ biosorption bySaccharomyces cerevisiae. J. Taiwan Inst. Chem. Eng. v. 43, p. 428-432, 2012.

GEANKOPLIS, C.J. Transport Processes and Unit Operations. $4^{\mathrm{a}}$ ed., EUA, PTR. Prentice Hall, 1993.

LEYVA-RAMOS, R; LANDIN-RODRIGUEZ, L.E.; LEYVA-RAMOS, S.; MEDELLINCASTILLO, N.A. Modification of corncob with citric acid to enhance its capacity for adsorbingcadmium(II) from water solution.Chem. Eng. J. v. 180,p. 113- 120, 2012.

LIMA, L. K. S.;PELOSI, B. T.; SILVA, M. G. C.; VIEIRA, M. G. A.Bioadsorção de $\mathrm{Cr}^{3+} \mathrm{em}$ macrófita aquáticaSalvinia natans. EncontroBrasileiroSobreAdsorção -EBA,2012.

LIMA, L. K. S.;SILVA,J. F. L.; SILVA, M. G. C.; VIEIRA, M. G. A.Lead biosorption by Salvinia natans Biomass: Equilibrium study. Chem. Eng. Trans. v. 38, 2014.IN PRESS.

LIMA, L. K. S.; KLEINÜBING, S. J.; SILVA, E. A.; SILVA, M. G. C. Removal of chromium from wastewater using macrophyte Lemnaminoras biosorbent. Chem. Eng. Trans. v. 25, p. 303-308, 2011.

MIRETZKY, P.;MUÑOZ, C. Enhanced metal removal from aqueous solution by Fenton activated macrophyte biomass. Desalination, v.271, p. 20-28, 2011.

PÉREZ MARÍN, A. B.; AGUILAR, M. I.; MESEGUER, V.F.; ORTUNO, J.F.; SÁEZ, J.; LLORÉNS, M. Biosorption of chromium (III) by orange (Citrus cinensis) waste: Batch andcontinuous studies. Chem. Eng. J. v. 155, p. 199-206, 2009.

SAYGIDEGER, S.; GULNAZ, O.; ISTIFLI, E. S.; YUCEL, N. Adsorption of Cd(II), Cu(II) and $\mathrm{Ni}(\mathrm{II})$ ions by Lemna minor L.: Effect of physicochemical environment. J. Hazard. Mater. v. 126, n. 1-3, p. 96-104, 2005.

SHENG P. X.; TING, Y. P.; CHEN, J. P.; HONG, L. sorption of lead, copper, cadmium, zinc and nickel by marine alagal biomass: characterization of biosorptive capacity and investigation of mechanisms, J. Colloid Interf. Sci. v. 275, p. 131-141, 2004.

VIEIRA, M.G.A.; OISIOVICI, R.M.; GIMENES, M.L.; SILVA, M.G.C. Biosorption of chromium(VI) using a Sargassum sp. packed-bed column. Bioresour. Technol. v. 99, p. 3094-3099, 2008.

VIJAYARAGHAVAN, K.: JEGAN, J.; PALANIVELU, K. ;VELAN, M. Batch and column removalof copper from aqueous solution using a brown marine alga Turbinariaornate. Chem. Eng. J. v. 106, p. 177-184, 2005.

VILAR, V. J. P.; LOUREIRO, J. M.; BOTELHO, C. S. M.; BOAVENTURA, R. A. R. Continuous biosorption of $\mathrm{Pb} / \mathrm{Cu}$ and $\mathrm{Pb} / \mathrm{Cd}$ in fixed-bed columnusing algae Gelidium and granulated agar extraction algal waste. J. Hazard. Mater. v. 154, p. 1173-1182, 2008.

WANG, X. S.; QIN, Y. Removal of Ni(II), Zn(II) and Cr(VI) from aqueous solution by Alternantheraphiloxeroides biomass. J. Hazard. Mater. v. 138, p. 582-588, 2006. 